Premise : Journal of English Education and Applied Linguistics

PP] $[\mathrm{EEE}$

https://fkip.ummetro.ac.id/journal/index.php/english

Gatcho and Hajan

\title{
WHAT IS SO SCARY ABOUT LEARNING ENGLISH? INVESTIGATING LANGUAGE ANXIETY AMONG FILIPINO COLLEGE STUDENTS
}

\author{
by \\ Al Ryanne Gabonada Gatcho \\ Trinity University of Asia, the Philippines \\ ryangatcho@yahoo.com \\ Bonjovi Hassan Hajan \\ José Rizal University, the Philippines \\ bonjovihajan36@gmail.com
}

Received: August 26, 2019

Resent: August 28, 2019

Accepted: September 28, 2019
Reviewed: August 27, 2019

Revised: September 27, 2019

Published: October 19, 2019

\begin{abstract}
:
Learning English as a foreign/second language is never a straightforward process. Several constraints may come along the way that tend to hinder students' learning. Studies have shown that the successes and failures of L2 learners in an English language classroom are dependent upon various psychological and social factors including anxiety. This study examined the English language learning anxiety of Filipino college students. The Foreign Language Classroom Anxiety survey adapted from Horwitz, Horwitz and Cope (1986) was administered to a group of 150 students randomly selected from 5 programs at a private university in the Philippines to identify students' anxiety level in terms of fear of negative evaluation, communication apprehension, fear of test, and anxiety of English class and to determine which factor is most probable to cause anxiety among them.. The results indicated that the students expressed different levels of anxiety among the four factors as majority provided answers ranging from neutral to strongly agree. However, it was discovered that fear of negative evaluation and communication apprehension were the most probable to cause anxiety among them. The study offers practical implications as to how L2 teachers can help students overcome their English anxiety and thus be successful in the learning of the target language.
\end{abstract}

Keywords: English Language, Filipino College Students, Language Learning Anxiety

\section{INTRODUCTION}

Learning English in this globalized world is vital and people from across the globe opt to study it as a foreign/second language. In fact, many countries embrace English as a second

Premise Journal Vol. 8 No 2, October 2019, e-ISSN: 2442-482x, p-ISSN: 2089-3345, p.127-143

Copyright@2019by PJEE 
language in their educational programs and children start their English education at a fairly young age. However, language educators find the teaching of English language as a challenging career choice as they deal with several factors including students' anxiety in learning the target language.

Anxiety in the field of foreign/second language learning has been studied extensively due to its adverse influence in the language acquisition process (see Bailey, 1983; Horwitz, Horwitz \& Cope, 1986; MacIntyre \& Gardner, 1994; Young, 1991; Ohata, 2005; Pappamihiel, 2002; Williams \& Andrade, 2008, as cited in, Lucas, Miraflores \& Go, 2011). It is defined as "a distinct complex of self-perceptions, beliefs, feelings, and behaviors related to classroom language learning arising from the uniqueness of the language learning process" (Horwitz, Horwitz, \& Cope, 1986, p. 128). Anxiety has been observed among language learners in such symptoms as "freezing" in class, "going blank" before exams, and feeling reticent about entering the classroom (Horwitz, Horwitz \& Cope, 1986, p. 128). In addition, English language students, as well as those learners studying a foreign language, experience anxiety when it comes to such classroom situations that involve speaking in front of a group of their fellow students or taking a test in a language other than their first language. With language anxiety, these learners tend to develop apprehension, worry, or even fear which lead them to have difficulty concentrating, becoming forgetful, sweating, and having palpitations.

According to MacIntyre and Gardner (1991), learners of both foreign and second language are likely to experience language anxiety and this in turn can pose possible problems "because it can interfere with the acquisition, retention, and production of the new language" (p. 86). Krashen (1985a, 1985b) posits that language anxiety constrains students' capacity to process language inputs and hinders the course of language acquisition. It means that when anxiety impairs mental function, students who are anxious have the tendency to acquire less and thus may be incapable of displaying what they have learned in the language class.

On a similar vein, studies have shown that language anxiety affects the communication strategies learners can use in a language class. Ely (1986), for instance, reported that anxious learners were less probable to take challenges in the language class.

Premise Journal Vol. 8 No 2, October 2019, e-ISSN: 2442-482x, p-ISSN: 2089-3345, p.127-143

Copyright@2019 by PJEE 
Likewise, Steinberg and Horwitz (1986) found that anxious learners communicated less explanatory and more concrete ideas than relaxed students. The findings discovered in these studies are in congruence with those researches conducted on other areas of specific communication anxiety which indicates that anxious learners are typically less productive in the language classroom than relaxed learners (Spolsky, 1989).

In the Philippines, although English language has been adopted as a lingua franca due to the country's rich linguistic diversity (Wa-Mbaleka, 2014b), Filipino students continue to face challenges in learning the second language (Berowa, 2018). Learning English as a second language can be difficult because it entails complex tasks that require psychological and social factors (Berowa, 2016). Thus, there is a need to find out the factors that may hinder or negatively affect English language learning among Filipino college students.

Lucas, Miraflores and Go (2011) studied language learning anxiety in the context of the Philippines. However, the sample used were foreign language learners studying in the Philippines. The results therefore failed to provide practical insights about the English language learning anxiety of Filipino college students especially in the Metropolitan area. A study by Berowa in 2018 could also serve as a good reference as far as English anxiety among Filipino language learners is concerned. However, the data were drawn merely from the South which makes the study inconclusive of its findings. Furthermore, a similar study by Macayanan, Quinto, Otsuka and Cueto (2018) as regards influence of language learning anxiety on L2 speaking and writing among Filipino students could not also be generalizable since only engineering students were part of the sample. Hence, a study on the examination of English anxiety and language learning from settings other than those studied is necessary.

The findings of this study will be useful in informing instructional practice of English language teachers especially those who are teaching the productive skills such as speaking and writing where anxiety among L2 learners is often anticipated. The study also brings in new insights and knowledge that can make significant addition to the existing literature on the area of English language learning anxiety.

In this study, the researchers specifically sought answers on the following research questions: 
1. What is the anxiety level of Filipino college students in learning English in terms of fear of negative evaluation, communication apprehension, fear of test, and anxiety of English class?

2. Which factor is most probable to cause anxiety among the students?

\section{METHOD}

\section{Design}

The study employed a descriptive-quantitative research design. The use of such design in this study was due to the purpose of the present research to provide quantitative description of students' English language learning anxiety in the English language classroom. By using this research design, it was expected that the results of the study could offer clear insights about the factors influencing the English language learning of the students.

\section{Participants}

This research was limited to the main campus of a private university situated in Manila, Philippines in which the 150 students, 83 male and 67 female from the four courses: (1) Bachelor of Science in Business Administration (BSBA), (2) Bachelor of Science in Information Technology (BSIT), (3) Bachelor of Science in Tourism Management (BSTM) and (4) Bachelor of Science in Hotel and Restaurant Management (BSHRM) were randomly selected.

\section{Instrument and Data Type}

The survey questionnaire used in this study consisted of two parts. The first part is about the demographic data of the respondents and the other one was the four-factor Foreign Language Classroom Anxiety scale originally developed by Horwitz et al. (1986) to measure English learning anxiety of the respondents. The researchers used this instrument as it has been very useful in gauging students' language learning anxiety across different contexts. The scale is composed of four subscales. Items 3, 7, 13, 15, 20, 23, 25, 31, and 33 measure fear of negative 
evaluation (Horwitz et al., 1986), items 1, 9, 14, 18, 24, 27, 29, and 32 measure communication apprehension (Horwitz et al., 1986) and items 2, 8, 10, 19, and 21 measure fear of tests (Horwitz et al., 1986), while item 4, 5, 6, 11, 12, 16, 17, 22,26, 28, 30 measure anxiety of English classes (Zhao, 2007). The respondents were asked to rate each item on a five-point Likert scale ranging from 1 (strong disagreement $\|$ ) to 5 (strong agreement $\|$ ).

\section{Data Collecting Technique}

The data were obtained using a survey questionnaire. The survey was a selfadministered questionnaire which students had to accomplish through forms. After answering the survey forms, the participants returned them personally to the researchers.

\section{Data Analysis Technique}

Since this study aimed at describing English language learning anxiety of the students, the researchers utilized descriptive statistics to analyze the data. Descriptive analysis as described by Bhattacherjee (2012) is the process in which constructs of interest are statistically described, aggregated, and presented. In this study, data were first tabulated and then analyzed using frequency count in order to describe specific anxiety students mostly experienced in learning the English language. The data analyzed were presented in tabular format per factor. The presentation of data was based on the research questions of the study.

\section{RESULTS AND DISCUSSION}

\section{Results}

Table 1 below presents the findings on the anxiety level of the students as regards fear of negative evaluation. Notably, item no. 33 which is "I get nervous when the English teacher asks questions which I haven't prepared in advance" got the highest number of responses to which the students strongly agreed (62). This clearly shows that being asked to speak English in the class entails preparedness among students. Students are likely to talk without hesitation when the topic they are assigned to discuss seems familiar to them or is something they have prepared for. Students also bring with them a fear that their classmates 
have better skills in the English language that they are. This is clearly shown in item no. 7 "I think that my classmates' English is better than mine" with the second highest number of strongly agree responses (45).

Table 1

Frequency distribution of the level of fear of negative evaluation

\begin{tabular}{|l|l|l|l|l|l|}
\hline Fear of Negative Evaluation & $\begin{array}{l}\text { SA } \\
(\mathbf{5})\end{array}$ & $\begin{array}{l}\text { A } \\
\mathbf{( 4 )}\end{array}$ & $\begin{array}{l}\text { NAd } \\
\mathbf{( 3 )}\end{array}$ & $\begin{array}{l}\text { D } \\
\mathbf{( 2 )}\end{array}$ & $\begin{array}{l}\text { SD } \\
\mathbf{( 1 )}\end{array}$ \\
\hline $\begin{array}{l}\text { 3. I tremble when I know that I'm going } \\
\text { to be asked to speak in English class }\end{array}$ & 16 & 32 & 57 & 25 & 20 \\
\hline $\begin{array}{l}\text { 7. I think that my classmates' English is } \\
\text { better than mine. }\end{array}$ & 45 & 31 & 40 & 24 & 10 \\
\hline $\begin{array}{l}\text { 13. It embarrasses me to volunteer } \\
\text { answers in my English class. }\end{array}$ & 17 & 61 & 31 & 24 & 17 \\
\hline $\begin{array}{l}\text { 15. I get depressed when I don't } \\
\text { understand what the teacher is } \\
\text { correcting. }\end{array}$ & 30 & 26 & 52 & 33 & 9 \\
\hline $\begin{array}{l}\text { 20. I feel my heart pounding when I am } \\
\text { going to be asked to speak in English } \\
\text { class. }\end{array}$ & 15 & 36 & 55 & 33 & 11 \\
\hline $\begin{array}{l}\text { 23. I always feel that my classmates } \\
\text { speak better English than I. }\end{array}$ & 15 & 39 & 61 & 18 & 17 \\
\hline $\begin{array}{l}\text { 25. English class moves so quickly that I } \\
\text { worry about getting left behind. }\end{array}$ & 14 & 32 & 52 & 22 & 30 \\
\hline $\begin{array}{l}\text { 31. I am afraid that my classmates will } \\
\text { laugh at me when I speak English. }\end{array}$ & 15 & 41 & 49 & 23 & 22 \\
\hline $\begin{array}{l}\text { 33. I get nervous when the English } \\
\text { teacher asks questions which I haven't } \\
\text { prepared in advance. }\end{array}$ & 62 & 22 & 36 & 24 & 6 \\
\hline Total & $\mathbf{2 2 9}$ & $\mathbf{3 2 0}$ & $\mathbf{4 3 3}$ & $\mathbf{2 2 6}$ & $\mathbf{1 4 2}$ \\
\hline
\end{tabular}

As can be gleaned from the table above, the students seem to indicate that clarity in teachers' corrections can contribute to their fear of negative evaluation as indicated by item no. 15 "I get depressed when I don't understand what the teacher is correcting" with 30 responses of strongly agree. This does not necessarily mean that students do not want to be corrected but a clear and proper way of correcting students' mistakes is important for students to lessen the fear to speak in English.

Moreover, it can be seen that volunteered answers, no background knowledge of the teacher's questions, pessimistic feeling that their classmate is better than they and the 
students' classmates laughing at them when they speak English are some of the important factors that teachers need to consider as well. Although the highest total number of responses across all statements in this category is neutral, looking at the statistics above one can say that fear of negative evaluation in general is likely to contribute to the anxiety level of students in learning English.

Displayed in Table 2 below are findings related to comprehension apprehension of students in the English classroom.

Table 2

Frequency distribution of the level of communication apprehension

\begin{tabular}{|l|l|l|l|l|l|}
\hline Communication Apprehension & $\begin{array}{l}\text { SA } \\
\mathbf{( 5 )}\end{array}$ & $\begin{array}{l}\text { A } \\
\mathbf{( 4 )}\end{array}$ & $\begin{array}{l}\text { NAd } \\
\mathbf{( 3 )}\end{array}$ & $\begin{array}{l}\text { D } \\
\mathbf{( 2 )}\end{array}$ & $\begin{array}{l}\text { SD } \\
\mathbf{( 1 )}\end{array}$ \\
\hline $\begin{array}{l}\text { 1. I never feel quite sure of myself } \\
\text { when I am speaking in my English } \\
\text { class. }\end{array}$ & 19 & 33 & 65 & 24 & 9 \\
\hline $\begin{array}{l}\text { 9. I start to panic when I have to speak } \\
\text { without preparation in English class. }\end{array}$ & 53 & 27 & 50 & 12 & 8 \\
\hline $\begin{array}{l}\text { 14. I will not be nervous when } \\
\text { speaking with native English } \\
\text { speakers. }\end{array}$ & 19 & 39 & 52 & 25 & 15 \\
\hline $\begin{array}{l}\text { 18. I feel confident when I speak in } \\
\text { English class. }\end{array}$ & 32 & 26 & 52 & 26 & 14 \\
\hline $\begin{array}{l}\text { 24. I feel shy when speaking English } \\
\text { in front of other students. }\end{array}$ & 32 & 29 & 61 & 22 & 6 \\
\hline $\begin{array}{l}\text { 27. I get nervous when I speak in my } \\
\text { English class. }\end{array}$ & 19 & 42 & 43 & 19 & 27 \\
\hline $\begin{array}{l}\text { 29. I get nervous when I don't } \\
\text { understand every word the English } \\
\text { teacher says. }\end{array}$ & 19 & 29 & 52 & 30 & 20 \\
\hline $\begin{array}{l}\text { 32. I feel easy when native English } \\
\text { speakers are with me. }\end{array}$ & 19 & 31 & 59 & 28 & 13 \\
\hline Total & $\mathbf{2 1 2}$ & $\mathbf{2 5 6}$ & $\mathbf{4 3 4}$ & $\mathbf{1 8 6}$ & $\mathbf{1 1 2}$ \\
\hline
\end{tabular}

It can be seen that "I start to panic when I have to speak without preparation in English class" is the statement where most students strongly agreed with a total number of 53 responses. This is consistent with the finding in Table 1 about the fear of negative evaluation when the students are being asked to speak in English by their teacher without preparation. Interestingly, while some students stated that they feel confident when speaking in English, others seem to be shy. This is shown in items 18 and 24 with similar result of 32 
SA responses from students. The split answer provided by students is fascinating in that it may imply that although they may have necessary lexical knowledge to express things out, they still need more exposure to build the confidence and eventually develop the skills to speak in English without apprehension. Across all items in this category, neutral still obtained the highest total number of responses from students (434) followed by agree and strongly disagree. Thus, it can be said that communication apprehension is a factor to consider in an English language classroom.

Table 3 presents the highest choice on fear of test (220) which illustrates the students' apprehension about the consequences of failing in their English class (73). This may suggest that an English test is a vital element of the students' successes and failures within the English classroom. In other words, students may be compelled to exert efforts in order to pass the test without necessarily being concerned about the communicative use of the English language in the long run. In connection to this, students indicated that they do not worry about making mistakes (53) which also connects with item no. 8 "I am usually at ease during tests in my class" (38). The positive perceptions students gave about English test may be due to the need for them to pass the test.

However, students stated that they are afraid that their English teacher checks every mistake that they give (38). This means that with certain amount of autonomy given to students and with proper way of correcting students' mistakes, students are likely to succeed in an English class. Overall, it can be argued that English tests are good ways of eliminating students' anxiety when teachers know how to correct students and when students are given tests not only for them to pass but also to use the language functionally.

Table 3

Frequency distribution of the level of fear of test

\begin{tabular}{|l|l|l|l|l|l|}
\hline Fear of test & $\begin{array}{l}\text { SA } \\
\mathbf{( 5 )}\end{array}$ & $\begin{array}{l}\text { A } \\
\mathbf{( 4 )}\end{array}$ & $\begin{array}{l}\text { NAd } \\
(\mathbf{3})\end{array}$ & $\begin{array}{l}\text { D } \\
\mathbf{( 2 )}\end{array}$ & $\begin{array}{l}\text { SD } \\
\mathbf{( 1 )}\end{array}$ \\
\hline 2. I don't worry about making mistakes & 53 & 38 & 37 & 22 & 0 \\
\hline $\begin{array}{l}\text { 8. I am usually at ease during tests in my } \\
\text { class }\end{array}$ & 38 & 41 & 47 & 24 & 0 \\
\hline $\begin{array}{l}\text { 10. I worry about the consequences of } \\
\text { failing my English class }\end{array}$ & 73 & 32 & 20 & 20 & 5 \\
\hline
\end{tabular}

Premise Journal Vol. 8 No 2, October 2019, e-ISSN: 2442-482x, p-ISSN: 2089-3345, p.127-143

Copyright@2019 by PJEE 


\begin{tabular}{|l|l|l|l|l|l|}
\hline $\begin{array}{l}\text { 19. I am afraid that my English teacher } \\
\text { will correct every mistake I make. }\end{array}$ & 38 & 32 & 46 & 26 & 8 \\
\hline $\begin{array}{l}\text { 21. the more I prepare for an English test, } \\
\text { the more confused I get. }\end{array}$ & 20 & 29 & 51 & 37 & 13 \\
\hline Total & $\mathbf{2 2 0}$ & $\mathbf{1 7 2}$ & $\mathbf{2 0 1}$ & $\mathbf{1 2 9}$ & $\mathbf{2 6}$ \\
\hline
\end{tabular}

As reflected in Table 4 below, majority of the students (364) do not feel tense and have no pressure in English classes.

Table 4

Frequency distribution of the level of anxiety of English classes

\begin{tabular}{|l|l|l|l|l|l|}
\hline Anxiety of English Class & $\begin{array}{l}\text { SA } \\
\mathbf{( 5 )}\end{array}$ & $\begin{array}{l}\text { A } \\
\mathbf{( 4 )}\end{array}$ & $\begin{array}{l}\text { And } \\
\mathbf{( 3 )}\end{array}$ & $\begin{array}{l}\mathbf{D} \\
\mathbf{( 2 )}\end{array}$ & $\begin{array}{l}\text { SD } \\
\mathbf{( 1 )}\end{array}$ \\
\hline $\begin{array}{l}\text { 4. I am afraid when I don't understand } \\
\text { what the teacher is saying in the English } \\
\text { class. }\end{array}$ & 36 & 31 & 47 & 30 & 6 \\
\hline $\begin{array}{l}\text { 5. It wouldn't bother me at all to take } \\
\text { more English classes. }\end{array}$ & 72 & 18 & 29 & 19 & 12 \\
\hline $\begin{array}{l}\text { 6. In English classes, I think of things that } \\
\text { are unrelated to the lesson. }\end{array}$ & 59 & 22 & 36 & 20 & 13 \\
\hline $\begin{array}{l}\text { 11. I don't understand why some people } \\
\text { get so upset over English class. }\end{array}$ & 59 & 32 & 35 & 15 & 9 \\
\hline $\begin{array}{l}\text { 12. In English class, I am so nervous that } \\
\text { I forget what I know. }\end{array}$ & 59 & 29 & 21 & 34 & 7 \\
\hline $\begin{array}{l}\text { 16. Even if I am well prepared for } \\
\text { English class, I feel anxious about it. }\end{array}$ & 46 & 32 & 48 & 15 & 9 \\
\hline $\begin{array}{l}\text { 22. I don't feel pressure to prepare very } \\
\text { well for English class. }\end{array}$ & 33 & 35 & 31 & 39 & 12 \\
\hline $\begin{array}{l}\text { 26. I feel tense and have more pressure in } \\
\text { English class than other classes. }\end{array}$ & 0 & 44 & 60 & 26 & 20 \\
\hline Total & $\mathbf{3 6 4}$ & $\mathbf{2 4 3}$ & $\mathbf{3 0 7}$ & $\mathbf{1 9 8}$ & $\mathbf{8 8}$ \\
\hline
\end{tabular}

This result is also marked by a response of 0 under strongly agree in item no 26. "I feel tense and have more pressure in English class than other classes". This finding is more elaborated in item no. 5 "It wouldn't bother me at all to take more English classes" (72). Item no. 11 "I don't understand why some people get so upset over English class" also comes in consonance with this result. This finding suggests that although certain factors may exist that could make students anxious about learning English, their favorable viewpoints about an English class affirm their willingness to learn the English language.

Premise Journal Vol. 8 No 2, October 2019, e-ISSN: 2442-482x, p-ISSN: 2089-3345, p.127-143 Copyright@2019 by PJEE 
Findings shown in table 5 summarize the level of frequency distribution of factors affecting language anxiety of the students. The result indicates that fear of negative evaluation and communication apprehension are more likely to cause English language learning anxiety of students. Fear of negative evaluations such as having to answer questions in English that they have not prepared for and minding that their classmates' English is what students are afraid about in their English classroom. In addition, such comprehension apprehensions as speaking about something without preparations and being shy of speaking in front of others constitute causes of students' English anxiety in learning the language.

Table 5

Level of frequency distribution of factors of language anxiety

\begin{tabular}{|l|l|l|l|l|l|}
\hline Factors & SA & A & NAd & D & SD \\
& $(\mathbf{5})$ & $\mathbf{( 4 )}$ & $\mathbf{( 3 )}$ & $\mathbf{( 2 )}$ & $\mathbf{( 1 )}$ \\
\hline Fear of Negative Evaluation & 229 & 320 & 433 & 226 & 142 \\
\hline Communication Apprehension & 212 & 256 & 434 & 186 & 112 \\
\hline Fear of Test & 220 & 172 & 201 & 129 & 26 \\
\hline Anxiety of English Classes & 364 & 243 & 307 & 198 & 88 \\
\hline
\end{tabular}

On the other hand, fear of test and anxiety of English classes are less likely to cause students' English language learning anxiety in the classroom. Students would usually feel at ease at taking English tests and that they do not worry about making mistakes. Moreover, they do not bother about taking more English classes and that they do not feel tensed or have no pressure about being in English classes.

\section{Discussion}

This study investigated the anxiety level of tertiary students in the English language classroom in terms of negative evaluation, communication apprehension, fear of test, and anxiety of English class and the factors that are most probable to cause anxiety among them. The findings show that students demonstrate different levels of anxiety among the four factors that were examined to cause their anxiety. This difference in levels was shown by the range of 
responses students provided from neutral to strongly agree across all statements under each factor.

Students revealed that fear of negative evaluation and communication apprehension were the most probable to cause their anxiety level. Specifically, students were found to be apprehensive about their teachers asking them questions that they have not prepared for and about their classmates having better English skills. These findings are consistent with the result of Tzoannopoulou (2016) which revealed that that factors that may provoke language anxiety are learners' communication apprehension with teachers and peers and teachers' corrections and criticisms. Fear of negative evaluation is experienced in situations in which language learners develop a feeling of being unable to manifest an appropriate social impression (Aydin, 2008). Additionally, Akkar (2015) pointed out a similar result indicating that fear of negative evaluation was the strongest to cause English language learning anxiety among students specifically in the area of oral communications.

As with communication apprehension, students were found to start panicking when asked to speak without preparations. They were also being shy speaking in front of other students. This corroborates the result of a study conducted by Wan Mustapha, Ismail and Ratan Singh (2010) where it was discovered that students tend to have higher level of communication apprehension when participating in public speaking. Along this line, Aydin (2008) illustrates that communication apprehension happens when language learners lack established communication skills even if they have developed ideas and thoughts. This is what the author calls as "the fear of getting into real communication with others" (Aydin, 2008, p. 423).

To address issues on communication apprehension in the context of L2 learning, Tom (2013) suggested that the learners be taught basic skills that require presentation, such as how to organize an individual presentation, methods to start and end a presentation, as well as verbal and non-verbal communication abilities. Furthermore, the author suggested that teachers provide activities that emphasize on enhancing students' pronunciation, and those engaging speaking activities that give students opportunity to speak. The influences of fear of negative evaluation and communication apprehension on students' English language learning have been noted in various previous studies (see Sellers 2000; Saito \& Samimy 1996; Cheng, Horwitz, \& Schallert, 1999). 
Interestingly, this study found that fear of test and anxiety of English class were as not as strongly persuasive as fear of negative evaluations and communication apprehension. In fact, students found that English tests allowed them to feel at ease as they were free to commit mistakes. This finding contradicts the result shown by Aydin (2009) where test anxiety can negatively influence students' motivation, concentration and achievement which eventually constraints them in translating their actual performance to test results. Moreover, it was revealed in this study that English class did not cause students to feel pressure. Instead, it made them like to take more English classes. This result is fascinating because previous findings such as those by Horwitz et al. (1986) and MacIntyre and Gardner (1991) unveiled that foreign language class constitutes the most anxiety-provoking factor for students. In this research, it is remarkable to note that even though the students may have shared anxiety towards learning English in general, they liked English class. This elucidates that when students have fully prepared for English class, there is a tendency that they do not feel anxious about learning English anymore.

\section{CONCLUSION AND SUGGESTIONS}

\section{Conclusion}

In conclusion, learning a foreign/second language is not without constraints. Several factors come along the way which may impede students' learning. Based on the findings of the study, it was concluded that the students expressed different levels of anxiety among the four factors as most of them provided answers ranging from neutral to strongly agree. However, of the four factors, fear of negative evaluation and communication apprehension were the most probable to cause anxiety among the students. It also revealed that the biggest causes of fear of evaluation among students were the questions asked by teacher in which the students were not prepared and the thoughts that their classmates' English is better than theirs. In addition, communication apprehensions such as speaking in front of others without preparation and being shy of doing so can potentially heighten the anxiety level of students. On the other hand, fear of test and anxiety of English classes did not have much influence on students' anxiety level as 
they felt at ease taking English tests and worried not about making mistakes. They also felt no pressure in English classes and did not worry about taking more English classes.

\section{Suggestions}

Drawing on the conclusions of this study, the following are suggested for L2 language teachers. First, L2 teachers should recognize the presence of the feeling of anxiety and tension among the language learners and should manage to think of immediate and effective techniques to help them overcome those obstructive feelings. Second, a truly communicative language teaching approach needs to be implemented to provide those language learners who have inadequate exposure to English language with more rooms to fully practice their oral communication skills. Of note is that L2 learners, despite some constraints, enjoy being in an English class and like to feel that they are free to make mistakes. Hence, language teachers should take this opportunity to enrich students' experiences in L2 learning. This is to build confidence among students and eventually develop skills to communicate without any apprehensions. Third, it is imperative that teachers create a welcoming, relaxed and learningsupportive English language classroom for language learners by means of displaying an approachable, accommodating and cooperative behavior that can make students feel at ease when speaking in the class. Fourth, to allow L2 learners feel a true sense of success and fulfilment in the English language classroom, language teachers should refrain from giving activities that trigger early frustration. Instead, they can begin with simple systematic lessons so that students can feel fulfilled and comfortable when taking part in class discussions for the first time. Fifth, language teachers should design and employ a highly communicative and authentic form of English tests to encourage language learners to practice micro skills needed in the English language so that they can develop positive feelings about being English language learners. Last, language teachers may need regular in-service training programs in human psychology including language anxiety in order to address certain issues related to students' stress and anxiety in an English classroom. 


\section{LIMITATION}

Despite the theoretical and pedagogical applications of this study, certain limitations are noted. This study has by far surveyed students only from 4 programs in the university. For a more encompassing and generalizable result, it is suggested that students from other programs be included. In addition, since the data came from only one university, the findings of this study may have issues in generalizing other contexts of Filipino college students. A quantitative research that reaches out to other universities with diverse students coming from different programs will help illuminate consistent patterns regarding English language learning anxiety of Filipino college students. Moreover, the findings in this study cannot address specific skills development in language areas as the focus was more on speaking. Macayanan et al. (2018) found that English anxiety was rather helpful in the writing performance of Filipino engineering students. This area on language learning may be an interesting field for further investigation. Lastly, a qualitative approach can be undertaken if the goal is to obtain in-depth information about the phenomenon concerning English language learning anxiety not only among Filipino college students but among second language learners in general.

\section{BIO-PROFILE}

Al Ryanne G. Gatcho is a full-time Faculty of English at the Trinity University of Asia, Philippines. He is currently writing his dissertation to obtain a $\mathrm{PhD}$ in Reading Education at the Philippine Normal University (PNU) where he also teaches in the graduate school of the said institution. He is a resource speaker for the Department of Education, particularly in seminars and trainings that aim to improve the pedagogical practices of reading teachers. Presently he is collaborating with other reading specialists at PNU for a research project funded by the Literacy Coordinating Council. His research interests include reading teachers' development, reading comprehension, multicultural literacy, and reading engagement. Corresponding email: ryangatcho@yahoo.com 


\section{BIO-PROFILE}

Bonjovi Hassan Hajan is a Research Faculty at the Senior High School Division in José Rizal University, Philippines. He is a M.A.Ed in English Language Teaching (ELT) candidate at the Philippine Normal University. He is a fellow at International Association of Scholars, Educators, Researchers and Practitioners (I-ASERP) and a teacher trainer at Asian Center of Education, Research and Training for Innovation (ACERT). Bonjovi also serves as a senior editor and a peer reviewer in reputable academic journals. His research publications explore the different areas of ELT including second language teaching and learning, teacher cognition, blended learning, academic writing, and discourse analysis. Corresponding email: bonjovihajan36@gmail.com

\section{REFERENCES}

Akkar, S. (2015). The effect of fear of negative evaluation on EFL learners' oral performance. University of Abderrahmane Mira, Bejaia Faculty of Arts and Languages Department of English.

Aydin, S. (2008). An investigation on language anxiety and fear of negative evaluation among Turkish EFL learners. Asian EFL Journal, 30(1),421-444

Aydin, S. (2009). Test anxiety among foreign language learners: A review of literature. Journal of Language and Linguistic Studies, 5(1), 127-137.

Berowa, A. M. (2016). The nose-bleed Syndrome: A study on the attitude of the college students towards English language learning and their linguistic self-confidence in a multicultural context. JPAIR Multidisciplinary Research, 24, 92-110.

Berowa, A. M. (2018). Levels of language anxiety toward English: A sample from Davao del Norte. The Online Journal of New Horizons in Education, 8(3), 118-128.

Bhattacherjee, A. (2012). Social science research: Principles, methods, and practices. Textbooks Collection. Book 3.

Cheng, Y., Horwitz, E. K., \& Schallert, D. L. (1999). Language anxiety: Differentiating writing and speaking components. Language Learning, 49, 417-449

Premise Journal Vol. 8 No 2, October 2019, e-ISSN: 2442-482x, p-ISSN: 2089-3345, p.127-143

Copyright@2019 by PJEE 
Ely, C. M. (1986). Language learning motivation: A descriptive and causal analysis. The Modern Language Journal, 70(5), 29-35.

Horwitz, E. K., Horwitz, M. B., \& Cope, J. A. (1986). Foreign language classroom anxiety. The Modern Language Journal, 70(2), 125-132. http://dx.doi.org/10.2307/327317

Krashen, S. D. (1985a). Applications of psycholinguistic research to the classroom. In C. James (Ed.), Practical applications of research in foreign language teaching (pp.51-66). Lincolnwood, IL: National Textbook Co.

Krashen, S. D. (1985b). The input hypothesis: Issues and implications. New York: Longman.

Lucas, R. I., Miraflores, E., \& Go, D., (2011). English language learning anxiety among foreign language learners in the Philippines. Philippine ESL Journal, 7, 94-119.

Macayanan, J. V., Quinto, E. J. M., Otsuka, J. C. \& Cueto, A. B. S. (2018). Influence of langauge learning anxiety on L2 speaking and writing of Filipino engineering students. 3L: The Southeast Asian Journal pf English Language Studies, 24(1), 40-55.

MacIntyre, P. D, \& Gardner, R. C. (1991). Methods and results in the study of anxiety and language learning: A review of the literature. Language Learning, 41, 85-117.

McCroskey, J. C. (1977). Oral communication apprehension: A summary of recent theory and research. Human Communication Research, 4, 78-96.

Saito, Y., \& Samimy, K. K. (1996). Foreign language anxiety and language performance: A study of learner anxiety in beginning, intermediate, and advanced-level college students of Japanese. Foreign Language Annals, 29, 239-251.

Sellers, V. D. (2000). Anxiety and reading comprehension in Spanish as a foreign language. Foreign Language Annals, 33, 512-521.

Spolsky, B. (1989). Conditions for second language learning. Oxford University Press, Oxford, UK.

Steinberg, F. S., \& Horwitz, E. K. (1986). The effect of induced anxiety on the denotative and interpretive content of second language speech. TESOL Quarterly, 20, 131-136.

Tom, A. A., Johari, A., Rozaimi, A., \& Huzaimah, S. (2013). Factors contributing to communication apprehension among pre-university students. Academic Journal of Interdisciplinary Studies, 2(8), 665.

Tzoannopoulou, M. (2016). Foreign language anxiety and fear of negative evaluation in the Greek university classroom. Selected papers on theoretical and applied linguistics, 21, 823-838. 
Wa-Mbaleka, S. (2014). English teachers' perceptions of the mother tongue-based education policy in the Philippines. European Journal of Research and Reflection in Educational Sciences, 2(4), 17-32.

Wan Mustapha, W. Z., Ismail, N., \& Ratan Singh, D. S. (2010). ESL students communication apprehension and their choice of communication activities. AJTLHE, 2(1), 22 -29.

Na, Z. (2007). A study of high school students' English learning anxiety. The Asian EFL Journal, 9(3), 22-34. 